\title{
Assessment of anthropogenic pressure on the environment in Rostov region
}

\author{
Alexander Khavanskiy ${ }^{1}$, Vladimir Latun ${ }^{*}, 1$, Yuliya Merinova ${ }^{1}$, Anastasiya Ivanchenko $^{1}$, and \\ Ludmila Nedoseka ${ }^{1}$ \\ ${ }^{1}$ Southern Federal University, Zorge str., 40, Rostov-on-Don, 344000, Russia
}

\begin{abstract}
Improvement of the methodology for determining the anthropogenic pressure on the region's environment, assessment of individual components and the total anthropogenic pressure, analysis of its formation and distribution in Rostov region. The main factors of anthropogenic impact on the environment are divided into four groups and presented in the form of demographic, industrial, agricultural and transport pressure, which, when summed up, give the total anthropogenic pressure. When determining certain types of anthropogenic pressure in the calculations, materials of statistical yearbooks and official data of regional reports on the state of the environment were used. For each type of anthropogenic pressure, indicators of anthropogenic impact and their numerical values were determined. The total anthropogenic pressure was determined by the sum of points. The features of the formation of anthropogenic pressure in Rostov region have been established. In cities with an industrial type of nature management, an increased and average anthropogenic pressure prevails. In rural areas of suburban urbanized zones and the development of mineral raw materials with an agrarian-industrial type of natural resource use, maximum indicators of environmental impact for agrarian areas, increased and average values of industrial, demographic and agricultural pressure have been established. Rural areas with an agrarian type, remote from industrial centers, are characterized by an increased agricultural pressure, lower and low values of the total pressure.
\end{abstract}

\section{Introduction}

At present, in many regions of Russia a significant anthropogenic impact is being exerted on the environment. The Russian environmental legislation contains a standard for the permissible anthropogenic pressure on the environment, but the way how to determine the anthropogenic pressure has not been established yet. In the scientific community, there are different approaches to assessing the anthropogenic pressure, including both complex studies [1-8] and component-wise analysis of pollution of the environment [9-15], as well as the study of the ecological state of the territory of the Rostov region [16]. However, a generally accepted method for its determination has not been developed.

\footnotetext{
${ }^{*}$ Corresponding author: vlatun@yandex.ru
} 
The main factors (sources) of impact on the environment in industrial areas are: emissions and discharges of pollutants, the formation and disposal of waste, in agricultural areas: plowing of land, disturbance of soil and vegetation cover, in all areas, the population and transport have a significant impact on the environment.

In the natural environment, all influencing factors are superimposed and a general anthropogenic pressure is formed. Therefore, to assess the anthropogenic impact on the environment, it is necessary to identify and analyze both individual sources of impact and the total anthropogenic pressure.

The purpose of this work is to improve the methodology for determining the anthropogenic pressure on the environment of the region, assess individual components and the total anthropogenic pressure, analyze its formation and distribution in Rostov region.

\section{Materials and research methods}

The main factors of anthropogenic impact on the environment are divided into four groups and presented in the form of demographic, industrial, agricultural and transport pressure. For each type of anthropogenic pressure, the main indicators of the negative impact on the environment and their numerical values have been determined. The summing up of these factors gives the total anthropogenic pressure.

Demographic pressure. In the course of life, the population uses natural resources, food, various items and products. After their use, waste water, wastes, air emissions and other types of environmental impact are generated. Each person consumes approximately the same amount of natural resources and generates a certain amount of wastes. Thus, the overall impact of a population on the environment depends on the size and density of the population.

To determine the demographic pressure, three indicators were used: population size, population density, and population change.

Industrial pressure. In modern conditions, industry is one of the main sources of adverse environmental impact. The main factors of industrial impact include: emissions of pollutants into the atmosphere from stationary sources, discharges of contaminated wastewaters into water bodies, disposal of industrial wastes into the environment. The consequences of industrialization have an impact on the state of many components of the natural environment [17]. When determining the industrial pressure, the above factors were taken into account.

Agricultural pressure. The impact of agriculture on the environment is manifested in the plowing of land, the use of powerful agricultural machinery, the application of mineral fertilizers and pesticides, the use of irrigation systems, an increase in the density of farm animals, etc. To determine the agricultural pressure, three indicators were used: the degree of plowing of the territory, the gross harvest of grain, livestock. These indicators are integral and largely (by 70-80\%) reflect the impact of agriculture on the environment.

Transportation pressure. Road transport has the greatest impact on the environment. In this regard, when determining the transportation pressure, indicators of the impact of vehicles on the environment were taken into account [17]. The main indicators of transportation pressure include: the number of vehicles, the volume of emissions into the atmosphere, the area of land under the roads.

When determining certain types of anthropogenic pressure in the calculations, materials of statistical yearbooks and official data of regional reports on the state of the environment were used $[18,19]$. The numerical values of the indicators of each type of anthropogenic pressure were determined for the administrative districts and urban districts, and the administrative units were grouped according to natural resource zones and types of nature management $[20,21]$. 
Indicators of certain types of anthropogenic pressure have different units of measurement, for their generalization, criteria were developed and an assessment was made on a 5-point scale (Table 1). For each type of pressure, the numerical values of the indicators were converted into points, the sum of points and the average score were determined, tables and maps were drawn up.

The total anthropogenic pressure is calculated as the arithmetic mean of the scores obtained in assessing the demographic, industrial, agricultural and transportation pressure for each administrative district or urban district.

Table 1. Indicators of anthropogenic pressure in the region.

\begin{tabular}{|c|c|c|c|c|c|c|}
\hline \multirow{2}{*}{$\begin{array}{l}\text { Anthropogeni } \\
\text { c pressure }\end{array}$} & \multirow{2}{*}{ Assessment indicators } & \multicolumn{5}{|c|}{ Graduation of point assessment of indicators, points } \\
\hline & & 1 & 2 & 3 & 4 & 5 \\
\hline \multirow[t]{3}{*}{ Demographic } & $\begin{array}{l}\text { 1. Population size - the } \\
\text { number of residents within } \\
\text { individual administrative } \\
\text { units, thousand people. }\end{array}$ & $<25$ & $25-50$ & $50-100$ & $100-300$ & $>300$ \\
\hline & $\begin{array}{l}\text { 2. Population density, people } \\
\qquad / \mathrm{km}^{2}\end{array}$ & $<20$ & $20-100$ & $100-1000$ & $1000-3000$ & $>3000$ \\
\hline & 3. Population change, & $<-20$ & $(-20):(-5)$ & $(-5):(+5)$ & $(+5):(+20)$ & $>+20$ \\
\hline \multirow{3}{*}{ Industrial } & $\begin{array}{l}\text { 1. Pollutant emissions into } \\
\text { the atmosphere from } \\
\text { stationary sources, tons } / \mathrm{km}^{2}\end{array}$ & $<0,1$ & $0,1-1,0$ & $1,0-10$ & $10-100$ & $>100$ \\
\hline & $\begin{array}{l}\text { 2. Discharges of pollutants } \\
\text { into water bodies, million } \mathrm{m}^{3} \\
\text { / year }\end{array}$ & $<0,1$ & $0,1-2$ & $2-10$ & $10-25$ & $>25$ \\
\hline & $\begin{array}{l}\text { 3. The amount of waste } \\
\text { generated, thousand tons / } \\
\text { year }\end{array}$ & $<10$ & $10-100$ & $100-500$ & $500-1000$ & $>1000$ \\
\hline \multirow{3}{*}{ Agricultural } & $\begin{array}{l}\text { 1. Gross harvest of grain, } \\
\text { thousand tons }\end{array}$ & $<50$ & $50-100$ & $100-150$ & $150-250$ & $>250$ \\
\hline & $\begin{array}{l}\text { 2. Livestock population, } \\
\text { conv. units heads } / \mathrm{km}^{2}\end{array}$ & $<3$ & $3-6$ & $6-9$ & $9-12$ & $>12$ \\
\hline & $\begin{array}{l}\text { 3. The degree of plowing of } \\
\text { the territory, } \% \text { of arable land }\end{array}$ & $<20$ & $20-40$ & $40-60$ & $60-80$ & $>80$ \\
\hline \multirow{3}{*}{ Transportation } & $\begin{array}{c}\text { 1. Number of vehicles, } \\
\text { thousand units }\end{array}$ & $<10$ & $10-20$ & $20-50$ & $50-100$ & $>100$ \\
\hline & $\begin{array}{l}\text { 2. Emission of pollutants, } \mathrm{t} / \\
\mathrm{km}^{2}\end{array}$ & $<3$ & $3-30$ & $30-100$ & $100-200$ & $>200$ \\
\hline & $\begin{array}{c}\text { 3. Land area under roads, } \% \\
\text { of the total area }\end{array}$ & $<3$ & $3-5$ & $5-10$ & $10-15$ & $>15$ \\
\hline
\end{tabular}

\section{Results and discussion}

Table 2 shows as an example indicators and a point estimation of the industrial pressure in Rostov region.

Similar tables have been drawn up for other types of anthropogenic pressure. The total anthropogenic pressure is presented in Table 3 and in Fig. 1.

The results of the assessment reveal the following features of the formation of anthropogenic pressure in Rostov region.

High values of the industrial, demographic and transportation pressure fall on urban districts, where the industrial type of nature management is represented and the main sources of environmental impact are concentrated.

The maximum values of the indicators of anthropogenic pressure have been established in the large industrial center of Rostov-on-Don. This anthropogenic pressure in the city was formed due to the high number and density of the population, a large volume of polluted wastewater discharge and emissions from vehicles. 
The cities of Novocherkassk, Taganrog, Volgodonsk belong to medium-sized industrial cities in which the electric power industry, ferrous metallurgy, machine building and metalworking, the chemical industry, and the construction industry are developed. Novocherkassk and Taganrog are characterized by high, Volgodonsk by average values of the total anthropogenic pressure. In Novocherkassk, the maximum industrial pressure is noted, and in Taganrog, the transportation pressure. The demographic pressure is high in Volgodonsk.

The cities of Azov and Bataysk are located near the city of Rostov-on-Don, due to which they are dynamically developing, have good infrastructure and promising territories for industrial and residential development. In Azov, there is a high level of transportation pressure, in Bataisk - transportation and demographic pressure.

In the mining towns, coal is mined and processed; enterprises in the electric power industry, mechanical engineering and metalworking, ferrous metallurgy and the food industry operate. The city of Shakhty, as a large coal mining center, is experiencing a high overall anthropogenic pressure. In other mining towns, the anthropogenic pressure is lower and varies from 3.1 to 3.7 points.

Table 2. Main indicators and assessment of industrial pressure in Rostov region.

\begin{tabular}{|c|c|c|c|c|c|c|c|c|}
\hline \multirow[t]{2}{*}{$\begin{array}{c}\text { Natural resource } \\
\text { zones and } \\
\text { administrative regions }\end{array}$} & \multicolumn{2}{|c|}{$\begin{array}{l}\text { Emission of } \\
\text { pollutants } \\
\text { into the } \\
\text { atmosphere }\end{array}$} & \multicolumn{2}{|c|}{$\begin{array}{l}\text { Discharge of } \\
\text { contaminated } \\
\text { waste water }\end{array}$} & \multicolumn{2}{|c|}{$\begin{array}{l}\text { The amount of } \\
\text { waste generated }\end{array}$} & \multirow{2}{*}{ 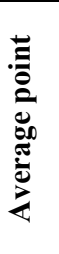 } & \multirow{2}{*}{ 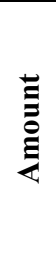 } \\
\hline & $\mathbf{t} / \mathbf{k m}^{2}$ & point & $\begin{array}{l}\mathbf{m l n} \\
\mathbf{m}^{3} / \mathbf{y e a} \\
\mathbf{r}\end{array}$ & point & $\begin{array}{l}\text { thousan } \\
\text { d t/year }\end{array}$ & point & & \\
\hline South-East & 9,4 & 2,8 & 156,0 & 2,5 & 2845,0 & 2,4 & 2,6 & 7,7 \\
\hline Rostov-on-Don & 34,4 & 4 & 117,0 & 5 & 659,9 & 4 & 4,3 & 13 \\
\hline Azov & 19,8 & 4 & 0,0 & 2 & 569,4 & 4 & 3,3 & 10 \\
\hline Bataysk & 8,7 & 3 & - & - & 82,6 & 2 & 2,5 & 5 \\
\hline Novocherkassk & 656,3 & 5 & 12,3 & 4 & 1246,4 & 5 & 4,7 & 14 \\
\hline Taganrog & 73,6 & 4 & 17,3 & 4 & 85,7 & 2 & 3,3 & 10 \\
\hline Azovsky & 0,2 & 2 & 0,0 & 1 & 26,1 & 2 & 1,7 & 5 \\
\hline Aksaysky & 3,8 & 3 & 3,0 & 3 & 49,0 & 2 & 2,7 & 8 \\
\hline Kuibyshevsky & 0,01 & 1 & 0,0 & 1 & 4,1 & 1 & 1,0 & 3 \\
\hline Matvevo-Kurgansky & 0,1 & 1 & 0,0 & 1 & 57,4 & 2 & 1,3 & 4 \\
\hline Myasnikovsky & 0,8 & 2 & 0,13 & 2 & 32,2 & 2 & 2,0 & 6 \\
\hline Neklinovsky & 0,5 & 2 & 0,08 & 1 & 24,9 & 2 & 1,7 & 5 \\
\hline $\begin{array}{l}\text { Rodionovo- } \\
\text { Nesvetaysky }\end{array}$ & 0,1 & 2 & 6,5 & 3 & 7,3 & 1 & 2,0 & 6 \\
\hline Donetsk & 11,5 & 3,1 & 69,8 & 2,7 & 3080,3 & 2,8 & 2,9 & 8,6 \\
\hline Shakhty & 22,0 & 4 & 13,2 & 4 & 949,3 & 4 & 4,0 & 12 \\
\hline Novoshakhtinsk & 4,4 & 3 & 3,72 & 3 & 46,7 & 2 & 2,7 & 8 \\
\hline Kamensk-Shakhtinsky & 26,2 & 4 & 23,2 & 4 & 195,4 & 3 & 3,7 & 11 \\
\hline Gukovo & 50,3 & 4 & 1,2 & 2 & 631,0 & 4 & 3,3 & 10 \\
\hline Donetsk & 3,5 & 3 & 1,7 & 2 & 14,5 & 2 & 2,3 & 7 \\
\hline Zverevo & 19,7 & 4 & 2,2 & 3 & 637,5 & 4 & 3,7 & 11 \\
\hline Belokalitvinsky & 1,5 & 3 & 3,0 & 3 & 103,5 & 3 & 3,0 & 9 \\
\hline Kamensky & 2,1 & 3 & 0,2 & 2 & 30,8 & 2 & 2,3 & 7 \\
\hline Krasnosulinsky & 2,0 & 3 & 2,2 & 3 & 210,7 & 3 & 3,0 & 9 \\
\hline Oktyabrsky & 0,6 & 2 & 20,9 & 4 & 240,7 & 3 & 3,0 & 9 \\
\hline Tatsinsky & 2,3 & 3 & 1,9 & 2 & 13,0 & 2 & 2,3 & 7 \\
\hline Ust-Donetsky & 0,1 & 1 & 0,36 & 2 & 7,0 & 1 & 1,3 & 4 \\
\hline Central & 0,6 & 2,0 & 35,7 & 2,4 & 189,2 & 1,6 & 2,0 & 6,0 \\
\hline Volgodonsk & 29,5 & 4 & 1,3 & 2 & 96,5 & 2 & 2,7 & 8 \\
\hline
\end{tabular}




\begin{tabular}{|c|c|c|c|c|c|c|c|c|}
\hline \multirow[t]{2}{*}{$\begin{array}{c}\text { Natural resource } \\
\text { zones and } \\
\text { administrative regions }\end{array}$} & \multicolumn{2}{|c|}{$\begin{array}{c}\text { Emission of } \\
\text { pollutants } \\
\text { into the } \\
\text { atmosphere }\end{array}$} & \multicolumn{2}{|c|}{$\begin{array}{c}\text { Discharge of } \\
\text { contaminated } \\
\text { waste water }\end{array}$} & \multicolumn{2}{|c|}{$\begin{array}{l}\text { The amount of } \\
\text { waste generated }\end{array}$} & \multirow{2}{*}{ 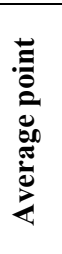 } & \multirow{2}{*}{$\stackrel{\vec{E}}{\grave{E}}$} \\
\hline & $\mathbf{t} / \mathbf{k m}^{2}$ & point & $\begin{array}{c}\mathbf{m l n} \\
\mathbf{m}^{\mathbf{3}} / \mathbf{y e a} \\
\mathbf{r}\end{array}$ & point & $\begin{array}{l}\text { thousan } \\
\text { d t/year }\end{array}$ & point & & \\
\hline Bagaevsky & 0,4 & 2 & 0,2 & 2 & 16,8 & 2 & 2,0 & 6 \\
\hline Veselovsky & 0,3 & 2 & 3,5 & 3 & 8,3 & 1 & 2,0 & 6 \\
\hline Volgodonskoy & 0,0 & 1 & 19,9 & 4 & 9,4 & 1 & 2,0 & 6 \\
\hline Konstantinovsky & 0,3 & 2 & 0,27 & 2 & 9,6 & 1 & 1,7 & 5 \\
\hline Martynovsky & 0,0 & 1 & 3,1 & 3 & 21,3 & 2 & 2,0 & 6 \\
\hline Proletarsky & 0,2 & 2 & 0,0 & 1 & 10,2 & 2 & 1,7 & 5 \\
\hline Semikarakorsky & 0,1 & 2 & 7,7 & 3 & 16,9 & 2 & 2,3 & 7 \\
\hline Southern & 0,4 & 1,7 & 3,6 & 1,8 & 259,4 & 2 & 1,8 & 5,5 \\
\hline Yegorlyksky & 0,0 & 1 & 0,1 & 2 & 9,8 & 1 & 1,3 & 4 \\
\hline Zernogradsky & 0,2 & 2 & 2,1 & 3 & 22,7 & 2 & 2,3 & 7 \\
\hline Kagalnitsky & 0,3 & 2 & 0,0 & 1 & 21,9 & 2 & 1,7 & 5 \\
\hline Peschanokopsky & 0,0 & 1 & 0,1 & 2 & 22,0 & 2 & 1,7 & 5 \\
\hline Salsky & 0,9 & 2 & 1,3 & 2 & 169,6 & 3 & 2,3 & 7 \\
\hline Tselinsky & 0,2 & 2 & 0,0 & 1 & 13,4 & 2 & 1,7 & 5 \\
\hline North-West & 0,6 & 1,9 & 1,1 & 1,1 & 375,2 & 1,6 & 1,5 & 4,6 \\
\hline Bokovsky & 0,0 & 1 & 0,0 & 1 & 6,6 & 1 & 1,0 & 3 \\
\hline Verkhnedonskoy & 0,0 & 1 & 0,0 & 1 & 8,9 & 1 & 1,0 & 3 \\
\hline Kasharsky & 0,0 & 1 & 0,0 & 1 & 7,8 & 1 & 1,0 & 3 \\
\hline Millerovsky & 1,2 & 3 & 1,1 & 2 & 316,8 & 3 & 2,7 & 8 \\
\hline Tarasovsky & 0,1 & 2 & 0,0 & 1 & 8,5 & 1 & 1,3 & 4 \\
\hline Chertkovsky & 0,4 & 2 & 0,0 & 1 & 16,0 & 2 & 1,7 & 5 \\
\hline Sholokhosky & 2,2 & 3 & 0,0 & 1 & 10,7 & 2 & 2,0 & 6 \\
\hline North-East & 0,1 & 1,2 & 1,6 & 1,8 & 229,9 & 1,4 & 1,5 & 4,4 \\
\hline Milutinsky & 0,0 & 1 & 0,0 & 1 & 8,7 & 1 & 1,0 & 3 \\
\hline Morozovsky & 0,4 & 2 & 0,5 & 2 & 195,5 & 3 & 2,3 & 7 \\
\hline Oblivsky & 0,0 & 1 & 0,0 & 2 & 8,1 & 1 & 1,3 & 4 \\
\hline Sovetsky & 0,0 & 1 & 0,7 & 2 & 8,9 & 1 & 1,3 & 4 \\
\hline Tsimlyansky & 0,1 & 1 & 0,4 & 2 & 8,7 & 1 & 1,3 & 4 \\
\hline South-East & 0,1 & 1,6 & 6,1 & 1,6 & 76,8 & 1,4 & 1,5 & 4,6 \\
\hline Dubovsky & 0,1 & 2 & 0,0 & 2 & 9,5 & 1 & 1,7 & 5 \\
\hline Zavetinsky & 0,0 & 1 & 0,0 & 1 & 4,3 & 1 & 1,0 & 3 \\
\hline Zimovnikovsky & 0,2 & 2 & 0,0 & 1 & 36,7 & 2 & 1,7 & 5 \\
\hline Orlovsky & 0,2 & 2 & 6,1 & 3 & 20,8 & 2 & 2,3 & 7 \\
\hline Remontnensky & 0,0 & 1 & 0,0 & 1 & 5,5 & 1 & 1,0 & 3 \\
\hline
\end{tabular}

Table 3. Total anthropogenic pressure in Rostov region

\begin{tabular}{|c|c|c|c|c|c|c|}
\hline \multirow{3}{*}{$\begin{array}{c}\text { Natural resource zones } \\
\text { and administrative } \\
\text { regions }\end{array}$} & \multicolumn{6}{|c|}{ Anthropogenic pressure, points } \\
\hline & \multirow{2}{*}{$\begin{array}{l}\text { Demo } \\
\text { graphi } \\
\text { c }\end{array}$} & \multirow{2}{*}{$\begin{array}{c}\text { Indu } \\
\text { stria } \\
\text { I }\end{array}$} & \multirow{2}{*}{$\begin{array}{l}\text { Agrica } \\
\text { Itural }\end{array}$} & \multirow{2}{*}{$\begin{array}{c}\text { Transpo } \\
\text { rtation }\end{array}$} & \multicolumn{2}{|c|}{ Total } \\
\hline & & & & & Sum of points & $\begin{array}{c}\text { Average } \\
\text { point }\end{array}$ \\
\hline South-East & 3,0 & 2,5 & 3,6 & 2,8 & 11,9 & 3,0 \\
\hline Rostov-on-Don & 4,3 & 4,3 & - & 4,7 & 13,3 & 4,4 \\
\hline Azov & 3,0 & 3,3 & - & 4,0 & 10,3 & 3,4 \\
\hline Bataysk & 4,0 & 2,5 & - & 3,3 & 9,8 & 3,3 \\
\hline Novocherkassk & 3,3 & 4,7 & - & 4,0 & 12,0 & 4,0 \\
\hline Taganrog & 4,3 & 3,3 & - & 4,3 & 12,0 & 4,0 \\
\hline
\end{tabular}




\begin{tabular}{|c|c|c|c|c|c|c|}
\hline \multirow{3}{*}{$\begin{array}{c}\text { Natural resource zones } \\
\text { and administrative } \\
\text { regions }\end{array}$} & \multicolumn{6}{|c|}{ Anthropogenic pressure, points } \\
\hline & \multirow{2}{*}{$\begin{array}{l}\text { Demo } \\
\text { graphi } \\
\text { c }\end{array}$} & \multirow{2}{*}{$\begin{array}{c}\text { Indu } \\
\text { stria } \\
\text { I }\end{array}$} & \multirow{2}{*}{$\begin{array}{l}\text { Agrica } \\
\text { Itural }\end{array}$} & \multirow{2}{*}{$\begin{array}{c}\text { Transpo } \\
\text { rtation }\end{array}$} & \multicolumn{2}{|c|}{ Total } \\
\hline & & & & & Sum of points & $\begin{array}{c}\text { Average } \\
\text { point }\end{array}$ \\
\hline City average & 3,8 & 3,6 & - & 4,1 & 11,5 & 3,8 \\
\hline Azovsky & 2,7 & 1,7 & 4,0 & 2,3 & 10,7 & 2,7 \\
\hline Aksaysky & 3,7 & 2,7 & 2,3 & 2,3 & 11,0 & 2,8 \\
\hline Kuibyshevsky & 1,7 & 1,0 & 3,3 & 1,0 & 7,0 & 1,8 \\
\hline Matvevo-Kurgansky & 2,0 & 1,3 & 4,0 & 1,7 & 9,0 & 2,3 \\
\hline Myasnikovsky & 3,0 & 2,0 & 4,0 & 2,0 & 11,0 & 2,8 \\
\hline Neklinovsky & 2,7 & 1,7 & 3,7 & 2,3 & 10,3 & 2,6 \\
\hline $\begin{array}{l}\text { Rodionovo- } \\
\text { Nesvetaysky }\end{array}$ & 1,3 & 2,0 & 3,7 & 1,0 & 8,0 & 2,0 \\
\hline Area average & 2,4 & 1,8 & 3,6 & 1,8 & 9,6 & 2,4 \\
\hline Donetsk & 2,5 & 2,8 & 3,2 & 2,5 & 11,0 & 2,8 \\
\hline Shakhty & 3,3 & 4,0 & - & 4,3 & 11,7 & 3,9 \\
\hline Novoshakhtinsk & 3,3 & 2,5 & - & 3,3 & 9,2 & 3,1 \\
\hline Kamensk-Shakhtinsky & 2,7 & 3,7 & - & 3,0 & 9,3 & 3,1 \\
\hline Gukovo & 3,7 & 3,3 & - & 4,0 & 11,0 & 3,7 \\
\hline Donetsk & 2,3 & 2,3 & - & 2,7 & 7,3 & 2,4 \\
\hline Zverevo & 1,7 & 3,7 & - & 2,7 & 8,0 & 2,7 \\
\hline City average & 2,8 & 3,3 & - & 3,3 & 9,4 & 3,1 \\
\hline Belokalitvinsky & 2,3 & 3,0 & 3,0 & 2,0 & 10,3 & 2,6 \\
\hline Kamensky & 1,7 & 2,3 & 3,7 & 1,7 & 9,3 & 2,3 \\
\hline Krasnosulinsky & 2,3 & 3,0 & 2,7 & 2,0 & 10,0 & 2,5 \\
\hline Oktyabrsky & 2,3 & 3,0 & 3,7 & 2,0 & 11,0 & 2,8 \\
\hline Tatsinsky & 1,7 & 2,3 & 3,7 & 1,3 & 9,0 & 2,3 \\
\hline Ust-Donetsky & 2,3 & 1,0 & 2,7 & 1,0 & 7,0 & 1,8 \\
\hline Area average & 2,1 & 2,4 & 3,2 & 1,7 & 9,4 & 2,4 \\
\hline Central & 2,2 & 2,0 & 3,6 & 2,6 & 10,4 & 2,6 \\
\hline Volgodonsk & 4 & 2,7 & - & 3,7 & 10,4 & 3,5 \\
\hline City average & 4 & 2,7 & - & 3,7 & 10,4 & 3,5 \\
\hline Bagaevsky & 2,3 & 2,0 & 3,0 & 1,7 & 9,0 & 2,3 \\
\hline Veselovsky & 2,0 & 2,0 & 3,7 & 1,3 & 9,0 & 2,3 \\
\hline Volgodonskoy & 2,0 & 2,0 & 3,0 & 1,3 & 8,3 & 2,1 \\
\hline Konstantinovsky & 1,7 & 1,3 & 3,7 & 1,3 & 8,0 & 2,0 \\
\hline Martynovsky & 2,0 & 2,0 & 4,0 & 1,3 & 9,3 & 2,3 \\
\hline Proletarsky & 1,7 & 1,7 & 4,0 & 1,3 & 8,7 & 2,2 \\
\hline Semikarakorsky & 2,0 & 2,3 & 3,7 & 2,0 & 10,0 & 2,5 \\
\hline Area average & 2,0 & 1,9 & 3,6 & 1,5 & 9,0 & 2,3 \\
\hline Southern & 2,1 & 1,8 & 4,1 & 1,6 & 9,6 & 2,4 \\
\hline Yegorlyksky & 2,0 & 1,3 & 3,7 & 1,7 & 8,7 & 2,2 \\
\hline Zernogradsky & 2,7 & 2,3 & 4,0 & 1,7 & 10,7 & 2,7 \\
\hline Kagalnitsky & 2,0 & 1,7 & 4,0 & 1,7 & 9,3 & 2,3 \\
\hline Peschanokopsky & 1,7 & 1,7 & 4,3 & 1,3 & 9,0 & 2,3 \\
\hline Salsky & 2,7 & 2,3 & 4,3 & 2,0 & 11,3 & 2,8 \\
\hline Tselinsky & 1,7 & 1,7 & 4,3 & 1,3 & 9,0 & 2,3 \\
\hline North-West & 1,8 & 1,5 & 3,0 & 1,2 & 7,5 & 1,9 \\
\hline Bokovsky & 1,7 & 1,0 & 2,7 & 1,0 & 6,3 & 1,6 \\
\hline Verkhnedonskoy & 1,3 & 1,0 & 2,3 & 1,0 & 5,7 & 1,4 \\
\hline Kasharsky & 1,3 & 1,0 & 3,7 & 1,0 & 7,0 & 1,8 \\
\hline Millerovsky & 2,7 & 2,7 & 4,0 & 1,7 & 11,0 & 2,8 \\
\hline Tarasovsky & 2,0 & 1,3 & 3,0 & 1,3 & 7,7 & 1,9 \\
\hline Chertkovsky & 1,7 & 1,7 & 2,7 & 1,3 & 7,3 & 1,8 \\
\hline
\end{tabular}




\begin{tabular}{|c|c|c|c|c|c|c|}
\hline \multirow{3}{*}{$\begin{array}{c}\text { Natural resource zones } \\
\text { and administrative } \\
\text { regions }\end{array}$} & \multicolumn{6}{|c|}{ Anthropogenic pressure, points } \\
\hline & \multirow{2}{*}{$\begin{array}{l}\text { Demo } \\
\text { graphi } \\
\text { c }\end{array}$} & \multirow{2}{*}{$\begin{array}{c}\text { Indu } \\
\text { stria } \\
\text { I }\end{array}$} & \multirow{2}{*}{$\begin{array}{l}\text { Agrica } \\
\text { Itural }\end{array}$} & \multirow{2}{*}{$\begin{array}{c}\text { Transpo } \\
\text { rtation }\end{array}$} & \multicolumn{2}{|c|}{ Total } \\
\hline & & & & & Sum of points & $\begin{array}{c}\text { Average } \\
\text { point }\end{array}$ \\
\hline Sholokhosky & 1,7 & 2,0 & 2,7 & 1,3 & 7,7 & 1,9 \\
\hline North-East & 1,5 & 1,5 & 3,3 & 1,1 & 7,4 & 1,9 \\
\hline Milutinsky & 1,3 & 1,0 & 3,3 & 1,0 & 6,7 & 1,7 \\
\hline Morozovsky & 1,7 & 2,3 & 4,0 & 1,3 & 9,3 & 2,3 \\
\hline Oblivsky & 1,3 & 1,3 & 3,0 & 1,0 & 6,7 & 1,7 \\
\hline Sovetsky & 1,3 & 1,3 & 3,0 & 1,0 & 6,7 & 1,7 \\
\hline Tsimlyansky & 1,7 & 1,3 & 3,0 & 1,3 & 7,3 & 1,8 \\
\hline South-East & 1,6 & 1,5 & 3,8 & 1,1 & 8,0 & 2,0 \\
\hline Dubovsky & 1,7 & 1,7 & 4,0 & 1,0 & 8,3 & 2,1 \\
\hline Zavetinsky & 1,3 & 1,0 & 3,0 & 1,0 & 6,3 & 1,6 \\
\hline Zimovnikovsky & 1,7 & 1,7 & 4,0 & 1,3 & 8,7 & 2,2 \\
\hline Orlovsky & 1,7 & 2,3 & 4,0 & 1,3 & 9,3 & 2,3 \\
\hline Remontnensky & 1,7 & 1,0 & 4,0 & 1,0 & 7,7 & 1,9 \\
\hline
\end{tabular}

Agricultural pressure for cities was not determined.

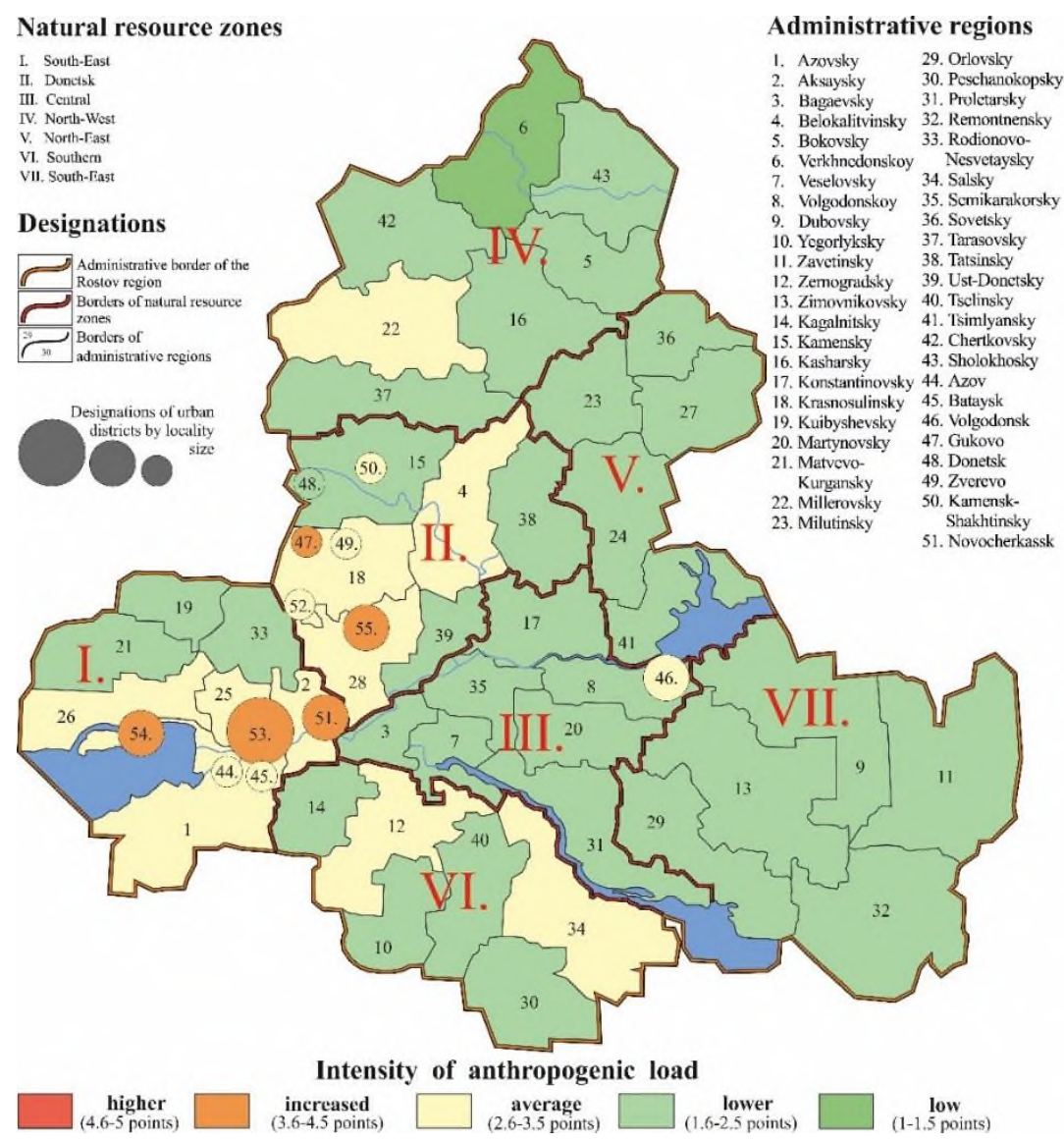

Fig. 1. Schematic map of the distribution of anthropogenic pressure in the Rostov region, 2016

As a result of the restructuring of the coal industry and the closure of many mines, in recent years in the cities of the Eastern Donbass, the anthropogenic impact has significantly decreased and the state of the environment has improved [21]. 
The agrarian-industrial type of nature management is implemented in rural areas of suburban urbanized zones of the Rostov agglomeration and in the coal mining zone of the Eastern Donbass.

Rural suburban areas of the Rostov agglomeration are included in the South-West natural resource zone. Here is a livestock and grain production with a developed suburban economy. Large and medium-sized industrial cities are located within this zone. The districts are characterized by an average industrial and transportation pressure, an increased agricultural pressure.

Rural areas of the Eastern Donbass belong to the Donetsk natural resource zone. Along with rural areas, small towns are located here, where there are industrial enterprises of power engineering, mechanical engineering, metallurgy, chemical, light and food industries. Agriculture is represented by the production of grain and sunflower, as well as cattle breeding with developed pig breeding. In these areas, the industrial and agricultural pressure has increased.

Rural areas of suburban urbanized zones and the development of mineral raw materials are characterized by the highest industrial pressure indicators for agrarian regions (Table 3), average values of demographic and agricultural pressure.

The agrarian type of nature management includes all the remaining districts of the Rostov region. In these areas one can distinguish agrarian-industrial centers and agrarian regions [21].

The agricultural and industrial centers of Salsky, Zernogradsky, Millerovsky and Morozovsky include small towns; have a small volume of industrial production, which specializes in processing agricultural products and servicing agricultural production. In agrarian-industrial centers, in comparison with other agrarian regions, the indicators of demographic, industrial and general anthropogenic pressure have increased by 1.5-2 times (Table 3).

In agrarian regions, cattle-breeding and grain specialization prevails, but depending on the location and intensity of production, they have different agricultural indicators. The southern districts of the region have higher indices, lower - peripheral northern and eastern districts. The average agricultural pressure in the South and South-East zones is 4.1, 3.8 points, in the North-West and North-East zones - 3.0, 3.3 points, with a relatively low total anthropogenic pressure. Due to intensive agricultural production, processes of degradation of the soil cover are common in most of the agricultural regions. Land desertification is taking place in the eastern districts of the region.

Rural areas of rainfed and irrigated agriculture occupy the central part of the Rostov region and are distinguished by cattle-breeding and vegetable-growing specialization with developed viticulture and rice cultivation. Irrigated agriculture is used in most areas of the Central Zone. However, outdated irrigation systems and their low technical level lead to a rise in groundwater, secondary salinization and waterlogging of soils. The area is distinguished by increased agricultural and reduced total anthropogenic pressure.

\section{Conclusion}

1. The methodology for determining the anthropogenic pressure on the region's environment has been improved, which includes an assessment of both individual types of pressure (demographic, industrial, agricultural and transport) and the total anthropogenic pressure, indicators and criteria for the point assessment of anthropogenic pressure have been developed.

2. In cities with an industrial type of nature management, an increased and average anthropogenic pressure prevails. The maximum values of anthropogenic pressure were established in a large industrial center - Rostov-on-Don, increased - in medium-sized 
industrial cities - Novocherkassk and Taganrog, in other cities an average anthropogenic pressure was revealed.

3. In rural areas with an agrarian-industrial type of nature management, located near large and medium-sized cities, the maximum industrial load indicators for agrarian areas, average values of the demographic and agricultural pressure have been established.

4. Rural areas with an agrarian type of nature management, remote from industrial centers, are characterized by a high agricultural pressure, low and low values of the total anthropogenic pressure.

\section{References}

1. R. Callaway, I. Fairley, J. Horrillo-Caraballo, Natural dynamics overshadow anthropogenic impact on marine fauna at an urbanised coastal embayment, Science of The Total Environment, 716, 137009 (2020)

2. J. Liang, Y. Li, Resilience and sustainable development goals based social-ecological indicators and assessment of coastal urban areas - A case study of Dapeng New District, Shenzhen, China, Watershed Ecology and the Environment, 2, 6-15 (2020)

3. D. Gouveia, C. Almunia, Y. Cogne, O. Pible, D. Degli-Esposti, A. Salvador, S. Cristobal, D. Sheehan, A. Chaumot, O. Geffard, J. Armengaud, Ecotoxicoproteomics: A decade of progress in our understanding of anthropogenic impact on the environment, Journal of Proteomics, 198, 66-77 (2019)

4. A. Hulme-Beaman, K. Dobney, T. Cucchi, J. B. Searle, An Ecological and Evolutionary Framework for Commensalism in Anthropogenic Environments, Trends in Ecology \& Evolution, 31(8), 633-645 (2016)

5. B. Hong, S. Yu, Y. Niu, J. Ding, Q. Lina, X. Lin, W. Hu, Spectrum and environmental risks of residual pharmaceuticals in stream water with emphasis on its relation to epidemic infectious disease and anthropogenic activity in watershed, Journal of Hazardous Materials, 385, 121594 (2020)

6. L. van den Heuvel, M. Blicharska, S. Masia, J. Sušnik, C. Teutschbein, Ecosystem services in the Swedish water-energy-food-land-climate nexus: Anthropogenic pressures and physical interactions, Ecosystem Services, 44, 101141 (2020)

7. T. Tarvainen, S. Reichel, I. Müller, I. Jordan, D. Hube, M. Eurola, K. LoukolaRuskeeniemi, Arsenic in agro-ecosystems under anthropogenic pressure in Germany and France compared to a geogenic as region in Finland, Journal of Geochemical Exploration, 217, 106606 (2020)

8. J. Fernández-Macho, P. González, J. Virto, Assessing anthropogenic vulnerability of coastal regions: DEA-based index and rankings for the European Atlantic Area, Marine Policy, 119, 104030 (2020)

9. G. G. Alexandrov, A. S. Ginzburg, Anthropogenic impact of Moscow district heating system on urban environment, Energy Procedia, 149, 161-169 (2018)

10. Y. Yu, J. Liu, W. Shao, The estimation and effect of anthropogenic heat flux in Beijing, Energy Procedia, 152, 302-306 (2018)

11. S. Bouslah, S. Tachi, A. Soufi, Impact of the Urbain and Industrial Rejection on the Environment «Annaba, North - Est Algeria», Energy Procedia, 18, 581-586 (2012)

12. M. Udvardi, E. L. Brodie, W. Riley, S. Kaeppler, Jonathan Lynch Impacts of Agricultural Nitrogen on the Environment and Strategies to Reduce these Impacts, Procedia Environmental Sciences, 29, 303 (2015) 
13. E. Balal, R. L. Cheu, A metric-concept map for scoping impact studies of a transportation project on environment and community health, International Journal of Transportation Science and Technology, 8, 176-191 (2019)

14. M. Sawadogo, D. Anciaux, D. Roy, Reducing intermodal transportation impacts on society and environment by path selection: a multiobjective shortest path approach, IFAC Proceedings, 23-25 (2012)

15. C. H. Hilde, M. Gamelon, B.-E. Sæther, J.-M. Gaillard, C. Pélabon, The Demographic Buffering Hypothesis: Evidence and Challenges, Trends in Ecology \& Evolution, 35(6) 523-538 (2020)

16. A. Khavanskiy, V. Latun, O. Khoroshev, Y. Merinova, L. Nedoseka, Risk assessment of hazardous abrasion and landslide processes in the coastal zone of the Azov Sea E3S Web of Conferences, 175, 06008 (2020)

17. Yu. Yu. Merinova, A. D. Khovanskiy, Yu. N. Merinov, Comprehensive assessment of the ecological state of urban districts of the Rostov region, Rostov-on-Don: Southern Federal University, 187 (2016)

18. Ecological Bulletin of the Don: On the state of the environment and natural resources in the Rostov region in 2016, Committee for the protection of the environment and natural resources of the administration of the Rostov region. Rostov n / a, 369 (2017)

19. Comparative indicators of the socio-economic situation of urban districts and municipal districts of Rostov region. 2016: Stat. Sat, Rostov-on-Don: Rostovstat, 392 (2017)

20. A. M. Kravchenko, A. N. Konovalov, I. V. Bessmertny, A. D. Khovanskiy, V. V. Latun, O. A. Khoroshev, Yu. Yu. Merinova, The natural potential of the landscapes of the Rostov region. News of higher educational institutions. North Caucasian region. Natural Sciences, 4, 62-70 (2019)

21. A. D. Khovanskiy, V. V. Latun, Yu. Yu. Merinova, I. V. Bogachev, O. A. Khoroshev, A. M. Kravchenko, Types of nature management and the ecological situation in the Rostov region, Ecology. Economy. Informatics. Series: Systems analysis and modeling of economic and ecological systems, 3 (2018) 